\title{
Physical education of students in the format of distance education
}

\author{
Marina Listkova* \\ Omsk State Pedagogical University, 644099, Omsk, Russia
}

\begin{abstract}
The current difficult situation with the spread of the COVID 2019 virus forced us to take a new look at the workflow and rebuild medicine as well as the entire education system. The rapid development of computer technologies over the past ten years allows education to find a reasonable way out of a difficult situation. Thus, the existing system of distance education helped to continue students 'education during the pandemic. The new format of education forced University lecturers (and other educational institutions) to look for the most appropriate and effective ways to implement the educational process. The Physical culture is not an exception. This article suggests and proves the most rational content of conducting remote physical education classes. They improve physical education help to maintain and strengthen the health of the younger generation.
\end{abstract}

\section{Introduction}

The Federal target program "Development of physical culture and sports in the Russian Federation for 2016-2020» put forward the main goal of "creating conditions that allow citizens to engage in physical culture and sports, and improving the effectiveness of training athletes in high-performance sports" [1, p. 1]. The main priority of the economic and social policy of the Federal program is to promote the standard of a healthy lifestyle, as well as to attract people to systematic physical education and sports in order to improve health.

An assessment of effectiveness from realization this program is a qualitative indicator. The economic effect of attracting the population to physical culture and sports shows reducing the number of days due to temporary disability of people. The increase in this indicator reflects positive achievements in the Federal program realization.

This program provides experimental developments and research for civil purposes [1, 2] to ensure the methodological development of the physical culture and sports organization. This task can be completed only if the scientific and experimental base is developed. On the basis of it the necessary conditions for the qualitative education will be formed.

The last changes in Russia make it necessary to seriously re-evaluate the role of physical culture for the entire population of the country.

Today students have to spend most of their time improving professional skills. It leads to a high emotional and informational load. In this situation, physical activity takes a back seat. The student often forgets the importance of a reasonable combination of work and rest. The universal use of computer and information technologies in work, training and leisure leads to a decrease in physical activity and problems with the musculoskeletal system [3].

The current difficult situation in the world with the spread of the COVID 2019 virus affected all people on earth without exception. According to statistics in Russia on 04.05.2020, 145452 people fell ill with coronavirus. The death rate was $0.94 \%$. Statistics of coronavirus infection cases in Russia are presented in Table 1 [4].

The coronavirus infection changed many of our habits and way of life. People who lead a healthy lifestyle are baffled how to behave in times of isolation and pandemics? Do I need to train during a pandemic? How do training sessions affect a person's immune system in response to a viral disease? How and how much can I train during a pandemic? What type of physical activity should I prefer?

Table 1. Statistics of coronavirus infection cases in Russia

\begin{tabular}{|l|l|l|l|l|l|}
\hline № & Region & Infections & Deaths & Recovers & \% Deaths \\
\hline 1. & Moscow & 74,401 & 764 & 7,573 & $1,03 \%$ \\
\hline 2. & Moscow region & 14,939 & 111 & 526 & $0,75 \%$ \\
\hline 3. & Saint Petersburg & 5,346 & 37 & 1,197 & $0,7 \%$ \\
\hline 4. & Nizhny Novgorod district & 2,852 & 16 & 383 & $0,57 \%$ \\
\hline
\end{tabular}

\footnotetext{
* Corresponding author: lest58@mail.ru
} 


\begin{tabular}{|c|c|c|c|c|c|}
\hline 5. & Murmansk district & 1,974 & 4 & 154 & $0,21 \%$ \\
\hline 6. & Republic of Dagestan & 1,958 & 13 & 226 & $0,67 \%$ \\
\hline 7. & Krasnodar region & 1,340 & 21 & 409 & $1,57 \%$ \\
\hline 8. & Tula region & 1,293 & 8 & 155 & $0,62 \%$ \\
\hline 9. & Rostov district & 1,263 & 10 & 123 & $0,8 \%$ \\
\hline 10. & Bryansk region & 1,250 & 12 & 294 & $0,96 \%$ \\
\hline 11. & Kaluga region & 1,217 & 12 & 128 & $0,99 \%$ \\
\hline 12. & Sverdlovsk region & 1,144 & 1 & 166 & $0,09 \%$ \\
\hline 13. & Ryazan region & 1,137 & 5 & 88 & $0,44 \%$ \\
\hline 14. & Republic of Tatarstan & 1,117 & 3 & 130 & $0,27 \%$ \\
\hline 15. & Republic of Bashkortostan & 1,102 & 14 & 185 & $1,28 \%$ \\
\hline 16. & Leningrad region & 1,096 & 3 & 220 & $0,28 \%$ \\
\hline 17. & Republic Of North Ossetia-Alania & 1,069 & 6 & 86 & $0,57 \%$ \\
\hline 18. & Kursk region & 997 & 4 & 126 & $0,41 \%$ \\
\hline 19. & Republic Of Ingushetia & 918 & 26 & 186 & $2.84 \%$ \\
\hline 20. & Vladimir district & 896 & 12 & 43 & $1,34 \%$ \\
\hline 21. & Republic of Mordovia & 867 & 4 & 98 & $0,47 \%$ \\
\hline 22. & Tambov region & 842 & 2 & 114 & $0,24 \%$ \\
\hline 23. & Krasnoyarsk region & 823 & 11 & 157 & $1,34 \%$ \\
\hline 24. & Republic Of Chuvashia & 795 & 8 & 134 & $1,01 \%$ \\
\hline 25. & Yaroslavl region & 789 & 5 & 100 & $0,64 \%$ \\
\hline 26. & Stavropol territory & 788 & 17 & 164 & $2,16 \%$ \\
\hline 27. & Chelyabinsk region & 784 & 3 & 96 & $0,39 \%$ \\
\hline 28. & Kabardino-Balkar Republic & 739 & 2 & 122 & $0,28 \%$ \\
\hline 29. & Republic Of Mari El & 717 & 4 & 416 & $0,56 \%$ \\
\hline 30. & Yamalo-Nenets Autonomous district & 712 & 3 & 129 & $0,43 \%$ \\
\hline 31. & Orenburg oblast & 700 & 4 & 217 & $0,58 \%$ \\
\hline 32. & The Republic Of Komi & 682 & 7 & 111 & $1,03 \%$ \\
\hline 33. & Novosibirsk region & 681 & 9 & 150 & $1,33 \%$ \\
\hline 34. & Orel & 681 & 7 & 123 & $1,03 \%$ \\
\hline 35. & Tver region & 680 & 6 & 115 & $0,89 \%$ \\
\hline 36. & Khabarovsk territory & 668 & 7 & 122 & $1,05 \%$ \\
\hline 37. & Saratov region & 659 & 3 & 99 & $0,46 \%$ \\
\hline 38. & Kirov region & 643 & 4 & 80 & $0,63 \%$ \\
\hline 39. & Voronezh region & 636 & 11 & 131 & $1,73 \%$ \\
\hline 40. & Perm region & 630 & 9 & 207 & $1,43 \%$ \\
\hline 41. & Republic of Chechnya & 583 & 8 & 286 & $1,38 \%$ \\
\hline 42. & Samara region & 578 & 5 & 59 & $0,87 \%$ \\
\hline 43. & Lipetsk region & 563 & 2 & 109 & $0,36 \%$ \\
\hline 44. & Tyumen region & 561 & 3 & 184 & $0,54 \%$ \\
\hline 45. & Primorsky Krai & 547 & 4 & 73 & $0,74 \%$ \\
\hline 46. & Penza region & 539 & 8 & 175 & $1,49 \%$ \\
\hline 47. & Altai territory & 534 & 2 & 82 & $0,38 \%$ \\
\hline 49. & Kaliningrad region & 524 & 9 & 114 & $1,72 \%$ \\
\hline 50. & Smolensk region & 520 & 4 & 81 & $0,77 \%$ \\
\hline 51. & Volgograd region & 516 & 12 & 91 & $2,33 \%$ \\
\hline 52. & Astrakhan region & 504 & 4 & 101 & $0,8 \%$ \\
\hline 53. & Belgorod region & 485 & 5 & 66 & $1,04 \%$ \\
\hline 54. & Ivanovo region Kurgan & 485 & 5 & 92 & $1,04 \%$ \\
\hline 55. & Khanty-Mansi Autonomous Okrug & 467 & 4 & 135 & $0,86 \%$ \\
\hline 56. & Karachay-Cherkess Republic & 441 & 2 & 35 & $0,46 \%$ \\
\hline 57. & Republic of Buryatia & 407 & 4 & 105 & $0,99 \%$ \\
\hline 58. & Novgorod region & 372 & 3 & 43 & $0,81 \%$ \\
\hline 59. & Kamchatka district & 339 & 0 & 37 & $0 \%$ \\
\hline 60. & Republic Of Kalmykia & 321 & 5 & 58 & $1,56 \%$ \\
\hline 61. & Udmurt Republic & 314 & 10 & 63 & $3,19 \%$ \\
\hline 62. & Republic Of Sakha (Yakutia) & 311 & 4 & 43 & $1,29 \%$ \\
\hline 63. & Republic Of Khakassia & 302 & 7 & 25 & $2,32 \%$ \\
\hline 64. & Arkhangelsk region & 299 & 1 & 81 & $0,34 \%$ \\
\hline 65. & Kostroma region & 266 & 3 & 60 & $1,13 \%$ \\
\hline
\end{tabular}




\begin{tabular}{|l|l|l|l|l|l|}
\hline 66. & Volgograd region & 223 & 0 & 75 & $0 \%$ \\
\hline 67. & Irkutsk region & 200 & 5 & 62 & $2,5 \%$ \\
\hline 68. & Zabaikalsky Krai & 198 & 0 & 67 & $0 \%$ \\
\hline 69. & Pskov region & 196 & 8 & 19 & $4,09 \%$ \\
\hline 70. & Republic Of Adygea & 185 & 6 & 98 & $3,25 \%$ \\
\hline 71. & Kemerovo region & 166 & 4 & 22 & $2,41 \%$ \\
\hline 72. & Omsk region & 161 & 3 & 31 & $1,87 \%$ \\
\hline 73. & Jewish Autonomous region & 145 & 0 & 15 & $0 \%$ \\
\hline 74. & Tomsk region & 128 & 1 & 27 & $0,79 \%$ \\
\hline 75. & Magadan region & 116 & 2 & 35 & $1,73 \%$ \\
\hline 76. & Republic Of Crimea & 105 & 0 & 39 & $0 \%$ \\
\hline 77. & Sevastopol & 91 & 2 & 11 & $2,2 \%$ \\
\hline 78. & Republic Of Karelia & 89 & 0 & 13 & $0 \%$ \\
\hline 79. & Amur region & 84 & 1 & 14 & $1,2 \%$ \\
\hline 80. & region & 52 & 0 & 16 & $0 \%$ \\
\hline 81. & Nenets Autonomous district & 47 & 0 & 1 & $0 \%$ \\
\hline 82. & Republic of Tuva & 47 & 0 & 29 & $0 \%$ \\
\hline 83. & Altai republic & 36 & 0 & 2 & $0 \%$ \\
\hline 84. & Sakhalin region & 28 & 0 & 19 & $0 \%$ \\
\hline 85. & Chukotka Autonomous Okrug & 24 & 0 & 2 & $0 \%$ \\
\hline & \multicolumn{2}{|c|}{ Total } & 145452 & 1358 & 18157 \\
\hline
\end{tabular}

Scientists proved that physical training can affect the immune system of the human body $[5,6,7,8,9,10,11$ etc.].

A Grand experiment conducted in 1998 by scientists from Hong Kong on 24,656 Chinese adults showed that light training 3 times a week can reduce the risk of death by the Hong Kong flu. The same time, people, who do not exercise or train very much (over 5 workouts per week), are most at risk of death [12, 13, 14, 15, 16, 17, 18, 19, 20 etc.].

Lyudmila Alimbarova, a leading researcher at the Gamalei Federal research center for epidemiology and Microbiology of the Russian Ministry of health, claims that research on the impact of physical activity on the possibility of Contracting influenza viruses has been conducted in Russia since the 1970s. The press service of the Ministry of health quotes her words: "The results of research show that the level of physical activity affects a person's resistance to infection. Those who do not play sports and are inactive in life are more likely to be infected with respiratory diseases. The same effect was observed in those who exercise excessively - with heavy loads and long recovery. The same athletes and Amateurs who exercise regularly and with a moderate degree of exercise showed an extremely low incidence of respiratory infections compared to the previous two groups" [21].

Researches conducted by American medical scientists in 2009 and 2015 in laboratory conditions on mice proved "that regular moderate exercise before infection has an anti-inflammatory effect in the local focus of infection", reduces the severity of the disease and viral load [22, 23].

What if you don't exercise regularly? Will the beginning of physical activity have a positive effect on the immune system? The answers to these questions were also obtained experimentally in mice. As a result of the research, scientists concluded that during the incubation period (the time between infection with the flu and the manifestation of its symptoms), moderate physical training for 20-30 minutes a day increases the chance of survival. The experiment showed that the number of surviving mice receiving physical activity for 20-30 minutes daily during the incubation period was $82 \%$. While the number of surviving "sedentary" mice was $43 \%$, the number of surviving mice that performed intense physical activity for 2.5 hours a day was $30 \%[24,25]$.

An interesting research was conducted among football players and athletes who specialize in cross-country. Strong training of these athletes led to a decrease of immunoglobulin level in the blood (IgA). Immunoglobulin (IgA) is an antibody (protein compounds of blood plasma) of the immune system. In response to the damaging effects of various antigens: microbes, viruses, bacteria, etc., antibodies bind to pathogenic microorganisms, block their reproduction and neutralize the toxic effect. Thus, immunoglobulins create the body's immune defense (humoral immunity). IgA is also closely related to upper respiratory tract infections. When the level of immunoglobulin in the body decreases, the number (frequency) of diseases increases. Experimental studies on the example of football players showed that during the lowest level of immunoglobulin in the blood, the most pronounced symptoms of infection were manifested. This was indirect evidence that excessive physical activity without adequate recovery makes the human body more vulnerable to virus attacks [26].

Exercise helps ease the course of the disease in people infected with coronavirus, as researchers at the American University of Virginia Graduate school of medicine confirm. We are talking about patients who are officially diagnosed with pneumonia. It developed against the background of infection. Scientists found that regular physical activity aimed at strengthening the cardiovascular system reduces the likelihood of developing acute respiratory distress syndrome (lung damage). It is deadly to humans. This complication occurs in $20-40 \%$ of those infected with coronavirus infection and in 50\% of cases leads to death. Experts note that during physical training, the human body naturally produces an antioxidant-extracellular superoxide dismutase (EcSOD). It reduces the likelihood of developing 
acute respiratory distress syndrome. In this regard, scientists recommend that every day for 30 minutes to pay attention to cardio training - walking, running, aerobics, cycling [27, 28, 29, etc.].

This information made us take a new look at the content of physical education classes, taking into account the distance learning students.

\section{Materials and methods}

The paper presents:

- General theoretical research methods-psychological and pedagogical analysis, sociological, reference and encyclopedic, valeological, normative and program documentation;

- empirical research methods-pedagogical experiment, pedagogical observation, questionnaire, survey, conversations, generalization of pedagogical experience, assessment of the psycho-emotional state, analysis of students ' activities;

- mathematical and statistical methods of processing materials of experimental work (quantitative and qualitative analysis of research results).

The experimental study was conducted in Russia, at Omsk State Pedagogical University with 1st-year students studying at various faculties of the University. The number of participants in the experiment was 54 students. The study was conducted during the period of distance learning of students associated with the outbreak of coronavirus infection in the country - from March to July 2020.

Purpose: substantiation, development and experimental verification of software for remote physical education classes for students.

Object: the process of students physical education during distance learning associated with an outbreak of viral infection.

The subject is the content of remote physical education classes for students.

For the full organization of students physical training in the framework of the discipline, each teacher must:

- know the material of the taught discipline in the scope of program requirements;

- master the methodology of preparation and provision of practical classes;

- conduct consultations within the course of practical training [30].

Physical education classes in a remote format set the task for teachers: to continue the educational process within the educational program of the University, to support and preserve the health of students, their immune system, improving their health, activity, and mood. Based on our previous experimental data, we can offer practical recommendations for independent physical training to students in the period of isolation and pandemic, as well as to people who lead a healthy lifestyle.

\section{Results and discussion}

We developed the content of independent physical education classes at the University [3]. Students ' distance learning was conducted at home. It was built on the basis of the previously developed content of classes (Fig. 1).

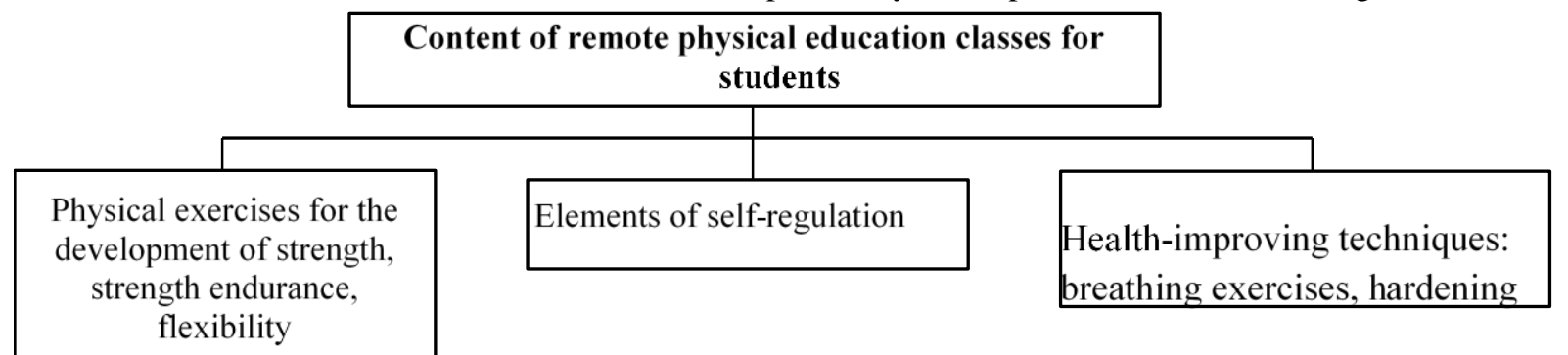

Fig. 1. Content of students' remote classes in physical culture

We offered students a video set of moderate-load exercises for 35-50 minutes. Then students were doused with cool or cold water. For each class, various complexes were offered that were not repeated throughout the semester. And if today's class was a yoga complex, then the next students were engaged in stretching, pilates, and so on. Each set included breathing exercises. Students made the tempering procedures at will, with absolute health [31]. Taking into account the difficult psychological atmosphere of 4 months of isolation, students were recommended to perform selfregulation exercises from self-training for 10-15 minutes during the day or before going to bed [3].

\section{Conclusions}

A variety of complexes and directions contributed to the development of students ' health and physical qualities, motivated interest in physical education, expanded knowledge in the field of physical culture, and introduced them to a healthy lifestyle. 
The "well-being, activity, mood" test [32] showed significant improvements in the emotional state of first-year students. The results of changes in the emotional state of first-year students $(n=54)$ before and after physical training and cold water dousing are presented in Table 2.

Table 2. Results of changes in the emotional state of first-year students before and after physical training and cold water dousing

\begin{tabular}{|c|c|c|c|c|c|c|c|c|}
\hline \multicolumn{3}{|c|}{ Well-being } & \multicolumn{3}{|l|}{ activity } & \multicolumn{3}{|l|}{$\operatorname{mood}$} \\
\hline before & after & \multirow[b]{2}{*}{$\mathrm{P}$} & before & after & \multirow[b]{2}{*}{$\mathrm{P}$} & before & after & \multirow[b]{2}{*}{$\mathrm{P}$} \\
\hline $\mathrm{X} \overline{ \pm m}$ & $\mathrm{X} \overline{ \pm m}$ & & $\mathrm{X} \overline{ \pm \mathrm{m}}$ & $\mathrm{X} \overline{ \pm \mathrm{m}}$ & & $\mathrm{X} \overline{ \pm \mathrm{m}}$ & $X \overline{ \pm m}$ & \\
\hline $5,1 \pm 1,38$ & $5,7 \pm 0,93$ & $<0,001$ & $4,7 \pm 1,36$ & $5,4 \pm 1,34$ & $<0,001$ & $5 \pm 1,37$ & $5,7 \pm 1,36$ & $<0,001$ \\
\hline
\end{tabular}

The proposed content of distance learning during the pandemic had a positive impact on the health, activity, and mood of students.

\section{References}

1. Federal program "Development of physical culture and sports in the Russian Federation for 2016-2020" (Government of the Russian Federation, 2017)

2. Decree of the Government of the Russian Federation On the Federal program "Development of physical culture and sports in the Russian Federation for 2016-2020" (2018)

3. M. L. Listkova, program of methodological support of students ' independent physical culture classes (Triumph publishing House, Moscow, 2020)

4. URL: https://pronedra.ru/statistika-zabolevaemosti-koronavirusom-v-rossii-474421.html

5. J.P. Campbell, N.E. Riddell, V.E. Burns, M. Turner, J.J. van Zanten, M.T. Drayson, J.A. Bosch, Brain Behav Immun, 23, $767-$ 775 (2009)

6. J.P. Campbell, and J.E. Turner, Front Immunol, 9, 648 (2018)

7. J.G. Cannon, J Appl Physiol, 74, 973-981 (1993)

8. A.J. Cox, M. Gleeson, D.B. Pyne, R. Callister, P.A. Fricker, and R.J. Scott, Exerc Immunol, 16, 8-21 (2010)

9. J.M. Davis, M.L. Kohut, L.H. Colbert, D.A. Jackson, A. Ghaffar, E.P. Mayer, J Appl Physiol, 83, 1461-1466 (1997)

10. A.D. Harper Smith, S.L. Coakley, M.D. Ward, A.W. Macfarlane, P.S. Friedmann, N.P. Walsh, Brain Behav Immun, 25, 1136$1142(2011)$

11. R.J. Simpson, H. Kunz, N. Agha, R. Graff, Prog Mol Biol Transl Sci, 135, 355-380 (2015)

12. J.E. Manson, P. Greenland, A.Z. LaCroix, M.L. Stefanick, C.P. Mouton, et al. N Engl J Med, 347, 716-725 (2002)

13. T.H. Lam, S.Y. Ho, A.J. Hedley, K.H. Mak, G.M. Leung, Ann Epidemiol., 14, 391-398 (2004)

14. D.C. Nieman, S.L. Nehlsen-Cannarella, Semin Hematol., 31, 166-179 (1994)

15. J.M. Davis, M.L. Kohut, L.H. Colbert, D.A. Jackson, A. Ghaffar, et al., J Appl Physiol., 83, 1461-1466 (1997)

16. A.S. Brown, J.M. Davis, E.A. Murphy, M.D. Carmichael, A. Ghaffar, et al., Med Sci Sports Exerc., 36, 1290-1295 (2004)

17. D.C. Nieman, S.L. Nehlsen-Cannarella, P.A. Markoff, A.J. Balk-Lamberton, H. Yang, et al., Int J Sports Med., 11, 467-473 (1990)

18. C.E. Matthews, I.S. Ockene, P.S. Freedson, M.C. Rosal, P.A. Merriam, et al., Med Sci Sports Exerc., 34, 1242-1248 (2002)

19. B. Macneil, L. Hoffmangoetz, A. Kendall, M. Houston Y. Arumugam, Journal of Applied Physiology, 70, 179-185 (1991)

20. D.C. Nieman, International Journal of Sports Medicine, 15, S131-141 (1994)

21. URL: https://tass.ru/obschestvo/8859991

22. M.L. Kohut, Y.-J. Sim, Sh. Yu, K.J. Yoon, Ch.M. Loiacono, The Journal of Infectious Diseases, 200(9), 1434-1442 (2009),

23. K.J. Warren, M.M. Olson, N.J. Thompson, M.L. Cahill, T.A. Wyatt, K.J. Yoon, Ch.M. Loiacono, M.L. Kohut, Exercise Improves Host Response to Influenza Viral Infection in Obese and Non-Obese Mice through Different Mechanisms (URL: https://doi.org/10.1371/journal.pone.0129713, 2015)

24. T. Lowder, D.A. Padgett, J.A. Woods, Brain, Behavior, and Immunity, 19(5), 377-380 (2005)

25. E.A. Murphy, J.M. Davis, M.D. Carmichael, J.D. Gangemi, A. Ghaffar, E.P. Mayer, Brain, Behavior, and Immunity, 22(8), 1152-1155 (2008)

26. M.M. Fahlman, H. Engels, Medicine \& Science in Sports \& Exercise, 37(3), 374-380 (2005)

27. URL: https://versia.ru/uchyonye-fizicheskie-uprazhneniya-pomogayut-legche-perenesti-koronavirus

28. A.J. Grande, J. Keogh, T.C. Hoffmann, E.M. Beller, and C.B. Del Mar, Exercise versus no exercise for the occurrence, severity and duration of acute respiratory infections (Cochrane Data-base Syst Rev Cd010596, 2015)

29. D.C. Nieman, L.M. Wentz, J Sport Health Sci, 8, 201-217 (2019)

30. Sample program of the discipline "Physical culture" (Ministry of higher education of the Russian Federation, 2000)

31. M. L. Listkova, Russian Journal of Physical Education and Sport, 15(2), 55-60 (2020) 
32. V. A. Doskin, N. A. Lavrentieva, M. P. Miroshnikov, V. B. Sharai, Questions of psychology: scientific and methodological journal, 6, 141-145 (1973) 